\title{
Wolf Reproduction in Response to Caribou Migration and Industrial Development on the Central Barrens of Mainland Canada
}

\author{
PAUL F. FRAME, ${ }^{1,2}$ H. DEAN CLUFF ${ }^{3}$ and DAVID S. HIK ${ }^{1}$
}

(Received 10 May 2007; accepted in revised form 2 August 2007)

\begin{abstract}
Reproductive success of mammals is greatly influenced by food availability. Where wolves (Canis lupus) prey on migratory barren-ground caribou (Rangifer tarandus), caribou migration patterns strongly influence food availability for wolves. However, industrial development in formerly undeveloped wolf range could also negatively influence wolf reproduction, either directly (by disrupting normal feeding behavior) or indirectly (by impacting caribou migrations). We used a cross-sectional timeseries regression to analyze eight years of wolf reproductive data with respect to spatial and temporal variation in caribou migration and economic development in a $49900 \mathrm{~km}^{2}$ area of the Northwest Territories, Canada. Reproductive success decreased as the distance from wolf dens to caribou migration routes increased, while the timing of caribou migrations had little effect. There was no measurable effect of current levels of economic development on reproductive success, although evidence suggests the potential for indirect effects. Continued monitoring is required to identify possible thresholds of adverse effects for wolf populations.
\end{abstract}

Key words: wolf, Canis lupus, caribou, Rangifer tarandus, cumulative effects, disturbance, migration, Northwest Territories, Nunavut, predator-prey, reproductive success

RÉSUMÉ. La réussite de reproduction des mammifères dépend beaucoup de la disponibilité de la nourriture. Là où les loups (Canis lupus) ont comme proie le caribou de la toundra en migration (Rangifer tarandus), le schéma des migrations du caribou joue un grand rôle sur la disponibilité de nourriture des loups. Cela dit, l'expansion industrielle dans d'anciennes aires de répartition non aménagées du loup pourrait aussi avoir une influence négative sur la reproduction du loup, directement (perturbation du comportement d'alimentation habituel) ou indirectement (impact sur la migration du caribou). Nous avons recouru à une régression chronologique transversale pour analyser huit années de données de reproduction du loup par rapport à la variation spatiale et temporelle de la migration du caribou et au développement économique dans une zone de $49900 \mathrm{~km}^{2}$ des territoires du Nord-Ouest, au Canada. La réussite de reproduction diminuait au fur et à mesure que la distance entre les tanières de loups et les routes de migration du caribou augmentaient, tandis que le moment choisi pour les migrations du caribou avait peu d'effets. Le développement économique actuel n'avait aucun effet mesurable sur la réussite de reproduction, bien que certains indices laissent croire qu'il pourrait avoir des effets indirects. Il y a donc lieu d'effectuer une surveillance continue afin de déterminer les seuils possibles d'effets nuisibles sur les populations de loups.

Mots clés : loup, Canis lupus, caribou, Rangifer tarandus, effets cumulatifs, perturbation, migration, Territoires du Nord-Ouest, Nunavut, prédateur-proie, réussite de reproduction

Traduit pour la revue Arctic par Nicole Giguère.

\section{INTRODUCTION}

Wildlife populations are regulated by the complex interactions of various factors, including weather, predation, food, and disease (Holmes, 1995). By investigating the influence of these factors on birth and death rates, we gain insights that improve our understanding of dynamic populations in dynamic natural systems (Krebs, 1995). An important factor influencing reproduction is food availability for mothers and their newborn young (Robbins, 1993; Elmhagen et al., 2000; Allen and Ullrey, 2004).
When food requirements are not satisfactorily met, reproductive rates decline (Wade and Schneider, 1992; Stirling et al., 1999; Elmhagen et al., 2000). Such declines can influence population numbers (Fuller, 1989; Stirling et al., 1999) and, depending on the species, can have cascading effects though entire ecosystems (Ripple and Beschta, 2003; Hamback et al., 2004; Hebblewhite et al., 2005).

For wolves (Canis lupus), access to adequate food is determined by their ability to find and kill sufficient numbers of large, hoofed prey animals (ungulates; Peterson and Ciucci, 2003; Fuller et al., 2003). Previous work has found

\footnotetext{
${ }^{1}$ Department of Biological Sciences, University of Alberta, Edmonton, Alberta T6G 2E9, Canada

${ }^{2}$ Corresponding author: pframe @ ualberta.net; current address: Nunavut Wildlife Management Board, P.O. Box 1379, Iqaluit, Nunavut X0A OH0, Canada

${ }^{3}$ Government of the Northwest Territories, Department of Environment \& Natural Resources, P.O. Box 2668, Yellowknife, Northwest Territories X1A 2P9, Canada

(C) The Arctic Institute of North America
} 
that reproductive success of wolves is most often related to prey availability, which has been quantified as total ungulate biomass per wolf per pack (Fuller, 1989; Fuller et al., 2003). For wolves dependent on migratory caribou (Rangifer tarandus), prey availability during denning (May-August) appears to be related to caribou movements (Kuyt, 1972; Heard and Williams, 1992; Heard et al., 1996; Frame et al., 2004; Frame, 2005). Both Kuyt (1972) and Williams (1990) reported that caribou were the main prey item for these barren-ground wolves throughout the summer.

Each year in the central barrens of northern Canada (Fig. 1), wolves follow caribou over hundreds of kilometres between winter ranges in the taiga and summer ranges on the tundra (Kuyt, 1962; Walton et al., 2001; Musiani, 2003). Although wolves associate with caribou throughout the year (Walton et al., 2001; Musiani, 2003; Frame et al., 2004), most wolves do not den near caribou calving grounds (Kuyt, 1972; Parker, 1973; Heard et al., 1996). Instead, they select sites closer to the tree line (Heard and Williams, 1992; Cluff et al., 2002). Consequently, there is a period during summer pup-rearing when most wolves are separated from their main prey by several hundred kilometres, and near the wolf dens, prey availability (total ungulate biomass per wolf) is low (Kuyt, 1972; Williams, 1990; Heard et al., 1996; Frame et al., 2004). Other authors have proposed that insufficient access to caribou during this time may influence wolf pup survival (Kuyt, 1972; Williams, 1990; Heard and Williams, 1992; Heard et al., 1996; Frame et al., 2004). Heard and Williams (1992) suggested that wolves may select den sites that expose them to the greatest number of caribou early in the autumn migration cycle. Frame et al. (2004) also reported that wolves will travel long distances to find caribou during times of local scarcity. However, the relative importance of these two migration parameters (timing of caribou movements or distance from wolf dens to caribou migration routes) remains unknown.

There are also concerns that cumulative effects of industrial development and tourism on the central barrens may negatively impact grizzly bears (Ursus arctos horribilis; Gau and Case, 1999; McLoughlin et al., 2000), wolverines (Gulo gulo; Mulders, 2001), and caribou (Griffith et al., 2002; Gunn et al., 2002; Johnson et al., 2005). Wolves may be vulnerable to disturbance during the pup-rearing period, when pack movements are restricted by the need to return food to immobile pups at dens (Walton et al., 2001; Frame et al., 2007). Some wolves are tolerant of human activity near their dens (Thiel et al., 1998; Frame et al., 2007), but others move pups to alternative sites in response to disturbance (Chapman, 1977; Ballard et al., 1987; Frame et al., 2007). While Ballard et al. (1987) and Frame et al. (2007) reported that no mortality occurred at dens where human disturbance caused wolves to move pups, it is possible that such disturbance can reduce reproductive success of wolves. However, the relation between industrial development and the reproductive success of wolves has not been studied previously in North America. Our objectives for this study, therefore, were to determine (1) whether human activity affects wolf reproduction and (2) whether the time when caribou migration begins or the location of wolf dens in relation to caribou migration routes affects the reproductive success of wolves.

\section{METHODS}

\section{Study Area}

Our study was conducted in the low Arctic tundra and forest-tundra transition zone of the central Canadian Arctic (Fig. 1). Study dens occurred in $49900 \mathrm{~km}^{2}$ centred in the Lac de Gras area, Northwest Territories, Canada $\left(64^{\circ} 27^{\prime} \mathrm{N}, 11^{\circ} 35^{\prime} \mathrm{W}\right)$, where diamond exploration and mining activities are established and have expanded rapidly in the past decade. This new development allowed us to study wolf reproductive success over a gradient of human activity intensities.

Boreal forest dominates the southwestern portion of the study area, but there is a transition to open tundra in the northeast (Timoney et al., 1992: Fig. 1). Standing water and exposed bedrock were common, with eskers, kames, and other glacial deposits occurring across the landscape. During the wolf denning period, the area was accessible only by aircraft.

Our study wolves denned in the range of the Bathurst herd of migratory barren-ground caribou, which was estimated at 186000 individuals in 2003 (Gunn et al., 2005). Wolves in the study area followed seasonal movements of the caribou (Walton et al., 2001; Musiani, 2003), their main prey (Kuyt, 1972; Williams, 1990). Most female caribou in this herd migrated out of the forest and onto the tundra by late April (Gunn et al., 2002). They reached calving grounds by early June, and by mid June most had given birth (Gunn et al., 2002). In general, newborn caribou calves begin to travel with the herd at one week of age (Kelsall, 1968), and bulls (though their movement patterns are not so well documented) are known to frequent areas near calving grounds by mid June (Heard et al., 1996; Gunn et al., 2002). After calving, female Bathurst caribou generally traveled south from calving grounds and then moved northwest parallel to the tree line. The rut usually takes place at the tree line in mid to late October (Gunn et al., 2002). The winter range of the Bathurst herd varied between years, ranging through the boreal forest and the forest-tundra ecotone south of Great Bear Lake to southeast of Great Slave Lake, while some caribou remained on the tundra all winter (Thorpe et al., 2001; Gunn et al., 2002).

During winter, wolves did not maintain territories. Instead, they followed caribou throughout their range (Walton et al., 2001; Cluff et al., 2002; Musiani, 2003). However, from May through August, while wolves were tending dens, a pack's movements were limited by the need to return food to the pups born between mid May and early June. From their analysis of wolf den locations, 


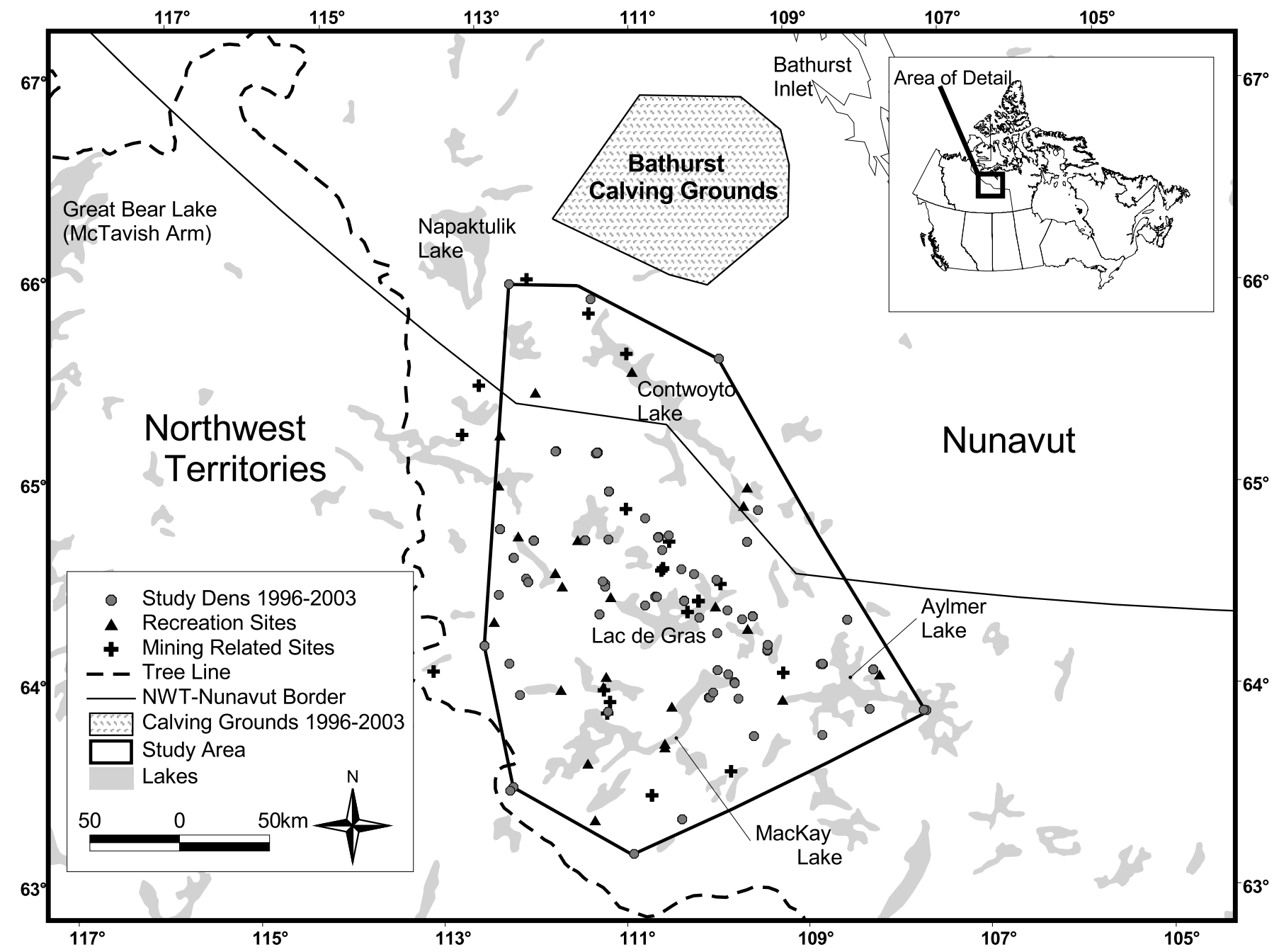

FIG. 1. Location of wolf dens, caribou calving grounds, and human development in the central Arctic of mainland Canada.

Heard and Williams (1992) suggested that wolves maximize access to migrating caribou by selecting den sites that are closer to the tree line (farther south) than to caribou calving grounds. Yet, because of caribou movement patterns, all tundra-denning wolves were separated from the main caribou herds by several hundred kilometres at some time during summer (Kuyt, 1972; Walton et al., 2001; Frame et al., 2004; Frame, 2005).

Muskoxen (Ovibos moschatus) occurred in limited numbers in the northeast portion of the study area (Fournier and Gunn, 1998) and likely supplemented the diet of some wolf packs (Kuyt, 1972). Occasionally moose (Alces alces) were seen in the southern extent of the study area, but their densities were low (H.D. Cluff, unpubl. data). Additional alternative prey included waterfowl and other groundnesting birds, eggs, rodents, and hares (Kuyt, 1972; Williams, 1990; Frame, 2005).

\section{Locating Dens}

Dens were initially located using a database of known wolf dens maintained by the Government of the Northwest
Territories (GNWT) and by investigating reports provided by other researchers (Cluff et al., 2002). From 1997 to 2003 (excluding 2000), 90 individual wolves were captured by helicopter net-gunning, chemically immobilized, and fitted with radio-collars as part of ongoing research in this population (Walton et al., 2001; Cluff et al., 2002; Musiani, 2003; Frame et al., 2004). To determine whether our capture operations influenced wolf reproduction, we used a T-test to compare years with capture to years with none. In spring (late May-early June), we used fixedwing aircraft to relocate radio-collared wolves and to survey known den sites for activity. Dens were considered active and became part of the study if wolves were observed there during the survey flight.

\section{Reproduction}

Pups were counted in late summer by flying over known active dens or relocating radio-collared adults at rendezvous sites from fixed-wing aircraft and counting the accompanying pups. Aerial counts were confirmed with ground observations when possible. The lack of trees in 
our study area allowed for reliable ground and aerial counts of pups by experienced observers. However, it is possible we missed some pups; therefore, our counts are minimum numbers.

\section{Caribou Monitoring}

Caribou locations were collected via satellite radio telemetry (Fancy et al., 1989; Gunn et al., 2002) from April 1996 through December 2003 as part of ongoing research and monitoring of the Bathurst herd (Gunn et al., 2002). Female caribou were radio-collared across their range for representative sampling of the herd. Caribou were captured by means of helicopter net-gunning (Gunn et al., 2002). During the calving and post-calving periods (early to late June), satellite collars recorded one location per day. During the rest of the year, one location was taken every five days, except in July and August 2003, when one location was acquired per day (Gunn et al., 2002). Locations of satellite-collared caribou were obtained by Service Argos Inc. (Landover, Maryland, USA).

We predicted that the dates on which caribou began migrating both north and south and the distance between migration routes and dens would influence caribou availability to wolves, and subsequently, reproductive success. Migration variables were calculated from caribou location data using ArcView Geographic Information System (GIS) software (Environmental Systems Research Institute Inc., Redlands, California, USA).

We estimated the mean date of migration onset for all satellite-collared caribou in both seasons of each migration cycle during the study (Table 1.) The beginning of the northern migration in spring was defined as the date when caribou were $50 \mathrm{~km}$ or more beyond the tree line and consecutive locations indicated directed movement. Southern migration was considered to begin on the date when caribou locations showed uninterrupted directed movement away from calving grounds.

To estimate annual caribou migration routes for both seasons, we drew a line connecting the consecutive locations of each individual caribou. We then measured the distance from each wolf den to the closest point along each line. We calculated the mean distance from all lines to each den in each year (1996-2003) and used this measure as the distance-to-migration-route variable (Table 1).

\section{Anthropogenic Landscape Features}

Human activity in the study area was related to mineral exploration and extraction, ecotourism, fishing, and hunting. Johnson et al. (2005) compiled a GIS data layer of human activity sites in the study area, which they used to analyze the viability of large mammal populations in the region. We used relevant portions of this same data layer for consistency among studies. The locations of mining and exploration activity were compiled from federal and territorial government records. Outfitting camp locations were taken from the GNWT Parks and Recreation operator database. Government personnel provided coordinates of winter road camps that, although inactive during the denning period (Johnson et al., 2005), have a crew of more than one individual to perform maintenance and upkeep through the summer.

To decrease the subjectivity inherent in assessing the potential impact of human activity on wolves, we generated and analyzed three human activity indices (primary, secondary, and maximum) for all known wolf dens in the study. In the primary index, fishing and hunting lodges, off-season winter road-maintenance camps, and a $26 \mathrm{~km}$ mine haul road (Misery pit road) were all assigned a relatively low value of five. While the impact of these sites on wolf behavior is unknown, they likely are similar to each other and have considerably less effect on wolves than mining activity. Mining exploration sites vary in intensity of activity; the most advanced ones have infrastructure similar to that of functional mines, but with less activity. Consequently these sites were assigned a value of eight. Active mines were assigned a value of 10 because the infrastructure footprint is considerable, and there are various degrees of truck and other heavy equipment traffic, regular air traffic, and about five rock blasts per week in mine pits.

For our secondary disturbance index, the effect of mining activity was considered to be an order of magnitude greater (exploration camps 80, active mines 100) than that of recreation sites (including winter road camps and the Misery pit road), which retained a score of five. For our maximum index, we considered all sites equal and assigned each a value of 100 .

Each den was buffered with a simulated circular summer home range of $1130 \mathrm{~km}^{2}$ (19 $\mathrm{km}$ diameter), which is equal to that of the average female wolf in this population (Walton et al., 2001). The value of each human feature within a simulated wolf home range was divided by its distance $(\mathrm{km})$ from the den, and the resulting values were summed. Thus, three standardized human activity indices were assigned to each den site.

\section{Data Analysis}

Because some dens were surveyed in multiple years, we used a cross-sectional time-series regression (Stata, 2003) to determine which of the independent variables-distance from each den to the mean estimated caribou migration route for both northern and southern migrations, mean start date of northern and southern migration, or the human activity index for each den-most influenced the dependent variable of number of pups per den. Each den's annual pup count was treated as an individual observation and grouped by year with the pup counts from other dens. Because this analysis has implications for environmental impact assessment, $p$-values less than 0.1 were considered to be significant in our statistical model (Steidl et al., 1997). 
TABLE 1. Summary of data used in an analysis of factors influencing late summer pup numbers at wolf dens in the central barrens of mainland Canada, expressed as mean values (SE). Analyses were based on the complete data set, which is not presented here.

\begin{tabular}{|c|c|c|c|c|c|c|c|}
\hline \multirow[b]{2}{*}{ Year } & \multirow[b]{2}{*}{ \# Dens } & \multirow{2}{*}{$\begin{array}{c}\text { Mean } \\
\text { Pups/Den (SE) }\end{array}$} & \multirow{2}{*}{$\begin{array}{c}\text { \# Collared } \\
\text { Caribou }\end{array}$} & \multicolumn{2}{|c|}{ Mean Julian Date of Migration Onset } & \multicolumn{2}{|c|}{ Mean Distance $(\mathrm{km})$ Dens to Migration } \\
\hline & & & & Northern (SE) & Southern (SE) & Northern (SE) & Southern (SE) \\
\hline 1996 & 7 & $3.4(0.69)$ & 7 & $117(3.64)$ & $171(1.41)$ & $53(3.32)$ & $42(5.46)$ \\
\hline 1997 & 8 & $4.0(0.76)$ & 7 & $121(4.61)$ & $178(0.46)$ & $54(8.89)$ & $29(3.70)$ \\
\hline 1998 & 11 & $3.1(0.73)$ & 7 & $112(3.56)$ & $173(1.34)$ & $82(11.54)$ & $53(4.22)$ \\
\hline 1999 & 7 & $3.0(0.98)$ & 14 & $129(0.97)$ & $179(1.37)$ & $90(21.10)$ & $58(8.90)$ \\
\hline 2000 & 12 & $3.8(1.19)$ & 13 & $121(1.41)$ & $184(1.91)$ & $103(7.95)$ & $61(8.11)$ \\
\hline 2001 & 14 & $0.6(0.37)$ & 13 & $129(0.76)$ & $194(1.35)$ & $91(8.27)$ & $110(3.19)$ \\
\hline 2002 & 10 & $4.1(0.92)$ & 16 & $134(0.93)$ & 185 (2.08) & $75(5.77)$ & $65(10.19)$ \\
\hline 2003 & 11 & $1.3(0.49)$ & 12 & $131(1.97)$ & $179(1.66)$ & $119(14.24)$ & $60(9.70)$ \\
\hline Mean & 10 & $2.7(0.31)$ & 11 & $124(0.80)$ & $182(0.72)$ & $86(4.25)$ & $64(3.56)$ \\
\hline
\end{tabular}

\section{RESULTS}

\section{Wolf Dens}

The mean number of dens surveyed per year during 1996-2003 was 10 (range 7-14, Table 1). During the entire study, 48 dens were surveyed and 29 of these were monitored in multiple years (range $1-7$ years), for a total of 80 data points of pups/den. Of 105 wolf captures, 15 were recaptures to remove radio collars. The annual percentage of surveyed packs that contained radio-collared wolves ranged from $0 \%$ in 1996 to $100 \%$ in $1999($ mean $=$ $68.7 \% \pm 10.9 \mathrm{SE})$. No wolves were captured in 1996 or in 2000. The greatest percentage of surveyed dens from which wolves were captured in a year was 86\% in 1999 (mean $=45.9, \pm 12.8 \mathrm{SE})$. We found no evidence that our capture operations influenced reproductive success $(\mathrm{T}=1.406, \mathrm{df}=78, p=0.16$, Table 1$)$.

\section{Reproduction}

The mean date for pup counts each year was 19 August (Julian date 231; range 214-248, or 2 August to 5 September). The mean number of pups/den (SE) ranged from $0.6( \pm 0.37)$ in 2001 to $4.1( \pm 0.92)$ in 2002 (Table 1). Overall, the mean number of pups/den was $2.7( \pm 0.31$, range $0-15)$.

\section{Caribou Migration}

The data on caribou migration are summarized in Table 1. The mean number of female caribou monitored each year was 11 (range 7-16). The overall mean date of northern migration onset (1996-2003) was 03 May (Julian date 124; range 112-134, or 21 April to 13 May), and the annual mean date of southern migration onset was 30 June (Julian date 182; range 171-194, or 21 June to 12 July). The mean annual northern migration route of all collared caribou was on average $86 \mathrm{~km}$ (range 53-119) from monitored wolf dens. For southern migration, the mean annual route of collared caribou was on average $64 \mathrm{~km}$ (range 29-110) from monitored wolf dens.

\section{Human Activity Index}

The number of active mine pits in the study area increased from zero in 1996 to four in 2003 (Table 2). The mean annual Human Activity Index for study dens ranged from 0.46 to 1.70 for the primary index, from 1.25 to 10.02 for the secondary index, and from 6.67 to 24.97 for the maximum disturbance index.

\section{Analysis}

The results for all three disturbance indices were similar $\left(R^{2}=0.21\right)$, so we will discuss only the primary index hereafter. The mean distance from dens to caribou migration routes, both northern $(Z=-1.78, p=0.076)$ and southern $(Z=-3.09, p=0.002)$, significantly influenced the number of pups at a den (Table 3 ). Neither the timing of migration onset (northern, $Z=-0.18, p=0.853$; southern, $Z=0.40, p=0.686$ ) nor the amount and type of human activity near dens $(Z=-0.19, p=0.851)$ had a significant influence on reproductive success (Table 3 ).

\section{DISCUSSION}

\section{Distance of Migration Routes from Dens}

It is reasonable to think that the spatial separation of denning wolves from their main prey for part of the summer influences reproductive success (Kuyt, 1972; Bergerud, 1988; Heard and Williams, 1992; Heard et al., 1996). In our study area, Heard and Calef (1986) and Heard et al. (1996) hypothesized that density-dependent caribou range expansion would make caribou available to denning wolves earlier in summer and thus improve pup survival, which, barring other influences, may contribute to an increase in wolf numbers. The results of our analysis indicate that the distance from wolf dens to caribou migration routes influences pup numbers more than the timing of caribou movements does. However, density-dependent range expansion is likely the mechanism behind distribution of caribou migration routes (Messier et al., 1988). With increasing herd size, caribou expand their range, 
TABLE 2. Number of anthropogenic landscape features in the study area (49900 $\mathrm{km}^{2}$ in the central barrens of mainland Canada) from 1996 to 2003. The last column shows the mean human activity index for each year. ${ }^{1}$ See Anthropogenic Landscape Features for details of index calculation.

\begin{tabular}{lcccc}
\hline \hline Year & Recreation & $\begin{array}{c}\text { Exploration } \\
\text { Camps }\end{array}$ & $\begin{array}{c}\text { Active } \\
\text { Mines }\end{array}$ & $\begin{array}{c}\text { Primary Human Activity } \\
\text { Index Mean (SE) }\end{array}$ \\
\hline 1996 & 26 & 12 & 0 & $0.57(0.15)$ \\
1997 & 26 & 12 & 0 & $0.46(0.21)$ \\
1998 & 26 & 12 & 1 & $0.76(0.38)$ \\
1999 & 26 & 17 & 1 & $0.91(0.59)$ \\
2000 & 26 & 16 & 1 & $0.75(0.37)$ \\
2001 & 27 & 15 & 2 & $1.03(0.41)$ \\
2002 & 27 & 15 & 3 & $1.31(0.68)$ \\
2003 & 27 & 14 & 4 & $1.70(0.70)$ \\
\hline \hline
\end{tabular}

${ }^{1}$ Results did not differ for the primary, secondary, and maximum indices; therefore, only the primary index is shown.

presumably to access adequate food resources (Heard and Calef, 1986; Messier et al., 1988). Such range expansion would bring more caribou closer to more dens; thus, on average, caribou availability to wolves would increase, and ultimately, so would pup survival (Fuller, 1989). Conversely, when caribou populations decrease, their range contracts (Messier et al., 1988); thus, on average, migration routes are farther from more wolf dens, and pup survival will decline.

Messier et al. (1988) believed that caribou of the George River herd in Quebec are unavailable to wolves during the four to five months of summer when pups are not mobile enough to travel with the pack. Likewise, Bergerud (1988) suggested that central Arctic wolves remain near the tree line and rely on alternative prey during denning. However, recent studies of denning wolves in the Bathurst caribou range show that they do travel long distances to encounter caribou during the sedentary denning period (Walton et al., 2001; Frame et al., 2004; H.D. Cluff, unpubl. data). Our analysis indicates an inverse relationship between reproductive success and the distance wolves must travel to caribou. This relationship is demonstrated by our data for 2001 (Table 1), which show the poorest year for reproduction corresponding to the greatest mean distance from dens to the southern caribou migration routes $(119 \mathrm{~km})$, which is $45 \mathrm{~km}$ more than wolves had to travel in 2002, the year with the next greatest distance. The closer caribou migration routes are to the den, the less time adult wolves spend securing food for pups. Shorter periods of time between feedings should increase net energy intake for pups, which should better their chance of surviving.

Our finding that southern migration was more important than northern migration could result from the fact that food requirements of wolf pups are proportional to their body size and growth rate (Heard and Williams, 1992). Growth rate is greatest when pups are 8 to 14 weeks old (Pulliainen, 1965; Kuyt, 1972), which generally corresponds to the period of southern migration. Therefore,
TABLE 3. Results of cross-sectional time-series regression evaluating the influence of caribou movement parameters and human development (primary index) on late summer wolf pup numbers. Eighty samples of 48 dens in an area of $49900 \mathrm{~km}^{2}$ were considered for the period 1996-2003.

\begin{tabular}{lcc}
\hline \hline Variable & Coefficient $( \pm \mathrm{SE})$ & $p$ \\
\hline Distance to Southern Migration Routes & $-0.036(0.012)$ & 0.002 \\
Distance to Northern Migration Routes & $-0.014(0.008)$ & 0.076 \\
Date of Southern Migration Onset & $0.027(0.066)$ & 0.686 \\
Date of Northern Migration Onset & $-0.009(0.050)$ & 0.853 \\
Human Activity Index & $-0.064(0.342)$ & 0.851 \\
Intercept & $2.567(10.009)$ & 0.798 \\
Model Fit, $\mathrm{R}^{2}$ & 0.21 & \\
\hline \hline
\end{tabular}

greater distance from dens to caribou migrating southward would limit nutrient availability during a critical period in pup development and would have a more significant effect on pup survival than distances to northern migration routes, which are relevant to a time when growth rates are lower. It appears that in 2001, the distance wolves had to commute to secure food was too great and the result was lower pup numbers.

\section{Onset of Migration}

Interestingly, the timing of seasonal migration onset had no significant influence on late summer pup numbers (Table 3). Both the timing of caribou migration and the travel routes vary from year to year (Kelsall, 1968; Kuyt, 1972; Gunn et al., 2002; Table 1). Thus, movements could begin earlier than normal in a given year, yet caribou would not be more available to wolves unless migration routes were also closer to dens.

\section{Anthropogenic Development}

The results of this study indicate that development at current levels is not having a detectable impact on wolf reproduction. Throughout North America, wolf populations persist in areas with significantly greater human development (i.e., roads, railways, etc.) than is currently present in the central barrens (Fuller, 1989; Mech, 1989; Thurber et al., 1994; Thiel et al., 1998; Hebblewhite et al., 2002; U.S. Fish and Wildlife Service et al., 2004). Although humancaused mortality can influence wolf numbers in these areas, local populations persist when adjacent to unexploited core populations (Fuller, 1989; Mech, 1989; Boyd and Pletscher, 1999).

At present the central barrens remain inaccessible by road except in winter. Lack of services along these winter routes limits public use. In our study area, road density during the denning period was $0.001 \mathrm{~km} / \mathrm{km}^{2}$. Additionally, the only year-round residences in the study area are associated with mining operations. Most human activity on the land takes place within tens of kilometres of mines and camps, decreasing as distance from the main site 
increases. Thus, while some individual dens may be influenced by mining, exploration, or recreation activity, most dens are not.

While development is not currently having a direct impact on wolf productivity in our study area, it is possible there could be an impact if development increases. Johnson et al. (2005) used a resource selection model to infer viability of large-mammal populations in a region that contains our study area at its center. They found that caribou avoid development in the post-calving period (late June through August). Nellemann and Cameron (1998) found that female-calf pairs displayed sensitivity to surface development. If females with calves are more sensitive to disturbance (Nellemann and Cameron, 1998) and therefore avoid development areas (Johnson et al., 2005), then further development of the central barrens may cause migration routes to change so that the commuting distance to caribou herds for wolves that den near such development becomes great enough to affect pup numbers. While the role of wolf predation in limiting caribou populations is not fully understood, wolves certainly are an important predator of the species (Bergerud, 1980, 1983; Messier et al., 1988; Haskell and Ballard, 2007). However, our results suggest that caribou movement patterns probably have a limiting effect on wolf numbers. Thus, we suggest that the behavior and population dynamics of these two species have likely co-evolved in this migratory system over millennia.

\section{Continued Monitoring of Wolves, Caribou, and Development}

Development is continuing with increased exploration activity in the central barrenlands of the Northwest Territories and Nunavut. While current levels of development are not having a measurable effect on late summer wolf pup numbers, the threshold at which wolves will begin to respond numerically is unknown and such thresholds are poorly understood at present. Continued monitoring of wolf reproduction, caribou movements, and human development will be required if land-use practices are to be managed to support healthy wild ecosystems.

\section{ACKNOWLEDGEMENTS}

This study was supported by the Department of Resources, Wildlife, and Economic Development (now Environment and Natural Resources), Government of the Northwest Territories; the Department of Biological Sciences at the University of Alberta; the Natural Sciences and Engineering Research Council of Canada; the Department of Indian and Northern Affairs Canada; the Canadian Circumpolar Institute; DeBeers Canada, Ltd.; BHP Billiton's Ekati Diamond Mine; Diavik Diamond Mines, Inc.; and the Aylmer Lake Lodge.

We thank L. Ruechel, G. Pflueger, D. Backman, T. Smith, M. Musiani, and L. Walton for assisting with den observations. The
Yellowknives Dene First Nation, Treaty 11 Council, North Slave Metis Alliance, and Lutsel K'e Dene Band supported this work and provided field assistants. P. Paquet made helpful comments on an earlier draft of this manuscript. This work was conducted under annual wildlife research permits issued by the Department of Resources, Wildlife, and Economic Development, Government of the Northwest Territories.

\section{REFERENCES}

ALLEN, M.E., and ULLREY, D.E. 2004. Relationships among nutrition and reproduction and relevance for wild animals. Zoo Biology 23:475-487.

BALLARD, W.B., WHITMANN, J.S., and GARDNER, C.L. 1987. Ecology of an exploited wolf population in south-central Alaska. Wildlife Monographs Suppl. 98, 51(3):3-54.

BERGERUD, A.T. 1980. A review of the population dynamics of caribou and wild reindeer in North America. In: Reimers, E., Gaare, E., and Skjenneberg, S., eds. Proceedings of the Second International Reindeer/Caribou Symposium. Trondheim, Norway. 556-581.

- 1983. The natural population control of caribou. In: Bunnell, F.L., Eastman, D.S., and Peek, J.M., eds. Symposium on natural regulation of wildlife populations. Moscow, Idaho: Forest, Wildlife and Range Experiment Station, University of Idaho. Proceedings No. 14:14-61.

1988. Caribou, wolves and man. Trends in Ecology and Evolution 3:68-72.

BOYD, D.K., and PLETSCHER, D.H. 1999. Characteristics of dispersal in a colonizing wolf population in the central Rocky Mountains. Journal of Wildlife Management 63:1094-1108.

CHAPMAN, R.C. 1977. The effects of human disturbance on wolves (Canis lupus L.). MSc thesis, University of Alaska Fairbanks.

CLUFF, H.D., WALTON, L.R., and PAQUET, P.C. 2002. Movements and habitat use of wolves denning in the central Arctic, Northwest Territories and Nunavut, Canada. Final Report to the West Kitikmeot/Slave Study Society, Yellowknife, Northwest Territories. http://www.nwtwildlife.com/WKSS/ PDF/EskerWolvesFinal.pdf.

ELMHAGEN, B., TANNERFELDT, M., VERUCCI, P., and ANGERBJÖRN, A. 2000. The arctic fox (Alopex lagopus): An opportunistic specialist. Journal of Zoology 251:139-149.

FANCY, S.G., PANK, L.F., WHITTEN, K.R., and REGELIN, W.L. 1989. Seasonal movements of caribou in Arctic Alaska as determined by satellite. Canadian Journal of Zoology 67: $644-650$.

FOURNIER, B., and GUNN, A. 1998. Musk ox numbers and distribution in the NWT, 1997. File Report No. 121. Yellowknife: Department of Resources, Wildlife, and Economic Development, Government of the Northwest Territories. $55 \mathrm{p}$.

FRAME, P.F. 2005. Response of wolves to caribou migration patterns and anthropogenic disturbance in the central Canadian Arctic. MSc Thesis, University of Alberta, Edmonton.

FRAME, P.F., HIK, D.S., CLUFF, H.D., and PAQUET, P.C. 2004. Long foraging movement of a denning tundra wolf. Arctic 57(2):196-203. 
FRAME, P.F., CLUFF, H.D., and HIK, D.S. 2007. Response of wolves to experimental disturbance at homesites. Journal of Wildlife Management 71:316-320.

FULLER, T.K. 1989. Population dynamics of wolves in northcentral Minnesota. Wildlife Monographs Suppl. 105, 53(4): 3-41.

FULLER, T.K., MECH, L.D., and COCHRANE, J.F. 2003. Wolf population dynamics. In: Mech, L.D., and Boitani, L., eds. Wolves: Behavior, ecology, and conservation. Chicago: University of Chicago Press. 161-191.

GAU, R.J., and CASE, R. 1999. Grizzly bear (Ursus arctos) studies in the Northwest Territories: Component No. 1, nutritional ecology. Final Report to the West Kitikmeot/Slave Study Society, Yellowknife, Northwest Territories. http://www.nwtwildlife. com/WKSS/PDF/GrizzlyNutritionalEcologyFinal.pdf.

GRIFFITH, B., GUNN, A., RUSSELL, D., JOHNSTONE, J., KIELLAND, K., WOLFE, S., and DOUGLAS, D.C. 2002. Bathurst caribou calving ground studies: Influence of nutrition and human activity on calving ground locations. Final Report to the West Kitikmeot/Slave Study Society, Yellowknife, Northwest Territories. http://www.nwtwildlife.com/WKSS/PDF/Bath CaribouNutritionFinal.pdf.

GUNN, A., DRAGON, J., and BOULANGER, J. 2002. Seasonal movements of satellite-collared caribou from the Bathurst herd. Final Report to the West Kitikmeot/Slave Study Society, Yellowknife, Northwest Territories. http://www.nwtwildlife. com/WKSS/SeasonalMovementsFinal.pdf.

GUNN, A., NISHI, J., BOULANGER, J., and WILLIAMS, J. 2005. An estimate of breeding females in the Bathurst herd of barrenground caribou, June 2003. Manuscript Report No. 164. Yellowknife: Department of Environment and Natural Resources, Government of the Northwest Territories.

HAMBACK, P.A., OKSANEN, L., EKERHOLM, P., LINDGREN, A., OKSANEN, T., and SCHNEIDER, M. 2004. Predators indirectly protect tundra plants by reducing herbivore abundance. Oikos 106:85-92.

HASKELL, S.P., and BALLARD, W.B. 2007. Modeling the western Arctic caribou herd during a positive growth phase: Potential effects of wolves and radiocollars. Journal of Wildlife Management 71:619-627.

HEARD, D.C., and CALEF, G.W. 1986. Population dynamics of the Kaminuriak caribou herd 1968-1985. Rangifer Special Issue 1:159-166.

HEARD, D.C., and WILLIAMS, T.M. 1992. Distribution of wolf dens on migratory caribou ranges in the Northwest Territories, Canada. Canadian Journal of Zoology 70:1504-1510.

HEARD, D.C., WILLIAMS, T.M., and MELTON, D.A. 1996. The relationship between food intake and predation risk in migratory caribou and implications to caribou and wolf population dynamics. Rangifer Special Issue 2:37-44.

HEBBLEWHiTE, M., PLETSCHER, D.H., and PAQUET, P.C. 2002. Elk population dynamics in areas with and without predation by recolonizing wolves in Banff National Park, Alberta. Canadian Journal of Zoology 80:789-799.

HEBBleWhite, M., White, C.A., NiETVELT, C.G., McKENZIE, J.A., HURD, T.E., FRYXELL, J.M., BALEY,
S.E., and PAQUET, P.C. 2005. Human activity mediates a trophic cascade caused by wolves. Ecology 86:2135-2144.

HOLMES, J.C. 1995. Population regulation: A dynamic complex of interactions. Wildlife Research 22:11-19.

JOHNSON, C.J., BOYCE, M.S., CASE, R.L., CLUFF, H.D., GAU, R.J., GUNN, A., and MULDERS, R. 2005. Cumulative effects of human developments on Arctic wildlife. Wildlife Monographs Suppl. 160, 69(3):1-36.

KELSALL, J.P. 1968. The migratory barren-ground caribou of Canada. Canadian Wildlife Service Monograph No. 3. Ottawa: Queen's Printer. 340 p.

KREBS, C.J. 1995. Two paradigms of population regulation. Wildlife Research 22:1-10.

KUYT, E. 1962. Movements of young wolves in the Northwest Territories of Canada. Journal of Mammalogy 43:270-271.

-1972. Food habits and ecology of wolves on barren-ground caribou range in the Northwest Territories. Canadian Wildlife Service Report Series 21. Ottawa: Information Canada. 36 p.

McLOUGHLIN, P.D., MESSIER, F., CASE, R.L., GAU, R.J., MULDERS, R., and CLUFF, H.D. 2000. The spatial organization and habitat selection patterns of barren-ground grizzly bears (Ursus arctos) in the Northwest Territories and Nunavut. Final Report to the West Kitikmeot/Slave Study Society, Yellowknife, Northwest Territories. http://www.nwtwildlife.com/WKSS/ PDF/SpatialHabitatGrizzlyFinal.pdf.

MECH, L.D. 1989. Wolf population survival in an area of high road density. American Midland Naturalist 121:387-389.

MESSIER, F., HUOT, J., LE HENAFF, D., and LUTTICH, S. 1988. Demography of the George River caribou herd: Evidence of population regulation by forage exploitation and range expansion. Arctic 41(4):279-287.

MULDERS, R. 2001. Wolverine ecology, distribution, and productivity in the Slave Geological Province. Final Report to the West Kitikmeot/Slave Study Society, Yellowknife, Northwest Territories. http://www.nwtwildlife.com/WKSS/PDF/Wolverine EcologyFinal.pdf.

MUSIANI, M. 2003. Conservation biology and management of wolves and wolf-human conflicts in western North America. PhD thesis, University of Calgary, Calgary, Alberta.

NELLEMAN, C., and CAMERON, R.D. 1998. Cumulative impacts of an evolving oil-field complex on the distribution of calving caribou. Canadian Journal of Zoology 76:1425-1430.

PARKER, G.R. 1973. Distribution and densities of wolves within barren-ground caribou range in northern mainland Canada. Journal of Mammalogy 54:341-348.

PETERSON, R.O., and CIUCCI, P. 2003. The wolf as a carnivore. In: Mech, L.D., and Boitani, L., eds. Wolves: Behavior, ecology, and conservation. Chicago: University of Chicago Press. $104-130$.

PULLIAINEN, E. 1965. Studies of the wolf (Canis lupus L.) in Finland. Annales Zoologici Fennici 2:215-219.

RIPPLE, W.J., and BESCHTA, R.L. 2003. Wolf reintroduction, predation risk, and cottonwood recovery in Yellowstone National Park. Forest Ecology and Management 184:299-313.

ROBBINS, C.T. 1993. Wildlife feeding and nutrition, 2nd ed. San Diego: Academic Press. 352 p. 
STATA. 2003. Cross-sectional time-series reference manual. College Station, Texas: Stata Corporation Press.

STEIDL, R.J., HAYES, J.P., and SCHAUBER, E. 1997. Statistical power analysis in wildlife research. Journal of Wildlife Management 61:270-279.

STIRLING, I., LUNN, N.J., and IACOZZA, J. 1999. Long-term trends in the population ecology of polar bears in western Hudson Bay in relation to climatic change. Arctic 52(3): 294-306.

THIEL, R.P., MERRILL, S., and MECH, L.D. 1998. Tolerance by denning wolves, Canis lupus, to human disturbance. Canadian Field-Naturalist 112:340-342.

THORPE, N., HAKONGAK, N., EYEGETOK, S., and QITIRMIUT ELDERS. 2001. Thunder on the tundra: Inuit qaujimajatuqangit of the Bathurst caribou. Ikaluktuuthak, Nunavut: Tuktu and Nogak Project.

THURBER, J.M., PETERSON, R.O., DRUMMER, T.D., and THOMASMA, S.A. 1994. Gray wolf response to refuge boundaries and roads in Alaska. Wildlife Society Bulletin 22: $61-68$.
TIMONEY, K.P., LAROI, G.H., ZOLTAI, S.C., and ROBINSON, A.L. 1992. The high subarctic forest-tundra of northwestern Canada: Position, width, and vegetation gradients in relation to climate. Arctic 45(1):1-19.

U.S. FISH AND WILDLIFE SERVICE, NEZ PERCE TRIBE, NATIONAL PARK SERVICE, and USDA WILDLIFE SERVICES. 2004. Rocky Mountain Wolf Recovery 2003 Annual Report. T. Meier, ed. Available from USFWS, Ecological Services, 100 N. Park, Suite 320, Helena, Montana 59601 and online at http://westerngraywolf.fws.gov/annualreports.htm. $65 \mathrm{p}$.

WADE, G.N., and SCHNEIDER, J.E. 1992. Metabolic fuels and reproduction in female mammals. Neuroscience and Biobehavioral Reviews 16:235-272.

WALTON, L.R., CLUFF, H.D., PAQUET, P.C., and RAMSAY, M.A. 2001. Movement patterns of barren-ground wolves in the central Canadian Arctic. Journal of Mammalogy 82:867-876.

WILLIAMS, T.M. 1990. Summer diet and behavior of wolves denning on barren-ground caribou range in the Northwest Territories, Canada. MSc thesis, University of Alberta, Edmonton, Alberta. 